\title{
Implementasi Undang-Undang Desa Nomor 6 Tahun 2014 Dalam Pengelolaan Dana Desa
}

\author{
Nety Hermawati \\ Institut Agama Islam Negeri Metro \\ Email : hermawatinety@gmail.com
}

\begin{abstract}
Village is a legal community unit that has the authority to manage its household based on the rights of origin and customs that are recognized in the National Government and in the Regency Region. Terminologically, the village is a legal community unit that has an original structure based on special origin rights. In order to advance the welfare of the community the government seeks to allocate village development assistance which is a form of government attention to the village. The assistance is given directly through the village to be distributed directly to the community so that the community can use it. It's just that, these assistance has not been channeled to the community, even the assistance is used by certain elements. The latest law on villages and village fund management is law number 6 of 2014, then, it is necessary to further examine how this implementation is carried out by village government officials.
\end{abstract}

Keyword : Village, Village Fund, Village Law

\begin{abstract}
Abstrak
Desa adalah kesatuan masyarakat hukum yang memiliki kewewenangan untuk mengurus rumah tangganya berdasarkan hak asal-usul dan adat istiadat yang diakui dalam Pemerintahan Nasional dan berada di Daerah Kabupaten. Secara terminologis, desa adalah sebagai kesatuan masyarakat hukum yang mempunyai susunan asli berdasarkasan hak asal-usul yang bersifat istimewa. Demi memajukan kesejahteraan masyarakat pemerintah berupaya untuk mengalokasikan bantuan pembangunan desa yang merupakan bentuk perhatian pemerintah kepada desa. Bantuan-bantuan tersebut diberikan secara langsung melalui desa untuk disalurkan langsung kepada masyarakat agar masyarakat dapat menggunakannya. Hanya saja, bantuan-bantuan tersebut belum tersalurkan kepada masyarakat, bahkan bantuan tersebut dimanfaatkan oleh oknum-oknum tertentu. Undang-undang terbaru tentang desa dan pengelolaan dana desa adalah undang-undang nomor 6 tahun 2014, maka, perlu kemudian untuk mengkaji lebih lanjut tentang bagaimana pengimplementasian ini oleh para aparatur pemerintah desa.
\end{abstract}

Kata Kunci : Desa, Dana Desa, Undang-undang Desa 
Istinbath: Jurnal Hukum

Website : http://e-journal.metrouniv.ac.id/index.php/istinbath/index

Received : 2019-04-10| Reviewed : 2019-05-11| Published : 2019-05-30.

(c) (†) (?)

This is an open access article distributed under the terms of the Creative Commons Attribution 4.0 International License, which permits unrestricted use, distribution, and reproduction in any medium, provided the original work is properly cited.

\section{Pendahuluan}

Sejak kemerdekaan 1945, Republik Indonesia tidak pernah memiliki kebijakan dan regulasi tentang desa yang kokoh, legitimate dan berkelanjutan. Perdebatan akademik yang tidak selesai, tarik menarik politik yang keras, kepentingan ekonomi politik yang menghambat, dan hasrat proyek merupakan rangkaian penyebabnya. Prof. Selo Soemardjan, Bapak Sosiologi Indonesia dan sekaligus promo-tor otonomi desa, berulangkali sejak 1956 menegaskan bahwa sikap politik pemerintah terhadap desa tidak pernah jelas.

Perdebatan yang berlangsung selalu berkutat pada dua hal. Pertama, debat tentang hakekat, makna dan visi negara atas desa. Kedua, debat politik-hukum tentang frasa kesatuan masyarakat hukum adat dalam UUD 1945 Pasal 18 B ayat (2) serta kedudukan desa dalam tata negara Republik Indonesia. Satu pihak mengatakan bahwa desa bukanlah kesatuan masyarakat hukum adat, melainkan sebagai struktur pemerintahan yang paling bawah. yang lain berpendapat, bahwa yang disebut kesatuan masyarakat hukum adat adalah desa atau sebutan lain seperti nagari, gampong, marga, kampung, negeri dan lain-lain yang telah ada jauh sebelum NKRI lahir.

Dua Undang-undang yang lahir di era reformasi, yakni UU No. 22/1999 dan UU No. 32/2004, ternyata tidak mampu menjawab pertanyaan tentang hakekat, makna, visi, dan kedudukan desa. Undang-Undang Nomor 6 Tahun 2014 tentang Desa merupakan instrumen untuk membangun visi menuju kehidupan Desa yang mandiri, demokratis dan sejahtera. Kemandirian desa dimaksudkan untuk menguatkan kontrol masayarakat terhadap pelaksanaan pembangunan yang telah sedang dan akan dilaksanakan di desa. 
Perspektif pelayanan publik desa, berdasarkan amanat Undang-undang Republik Indonesia Nomor 6 Tahun 2014 Pasal 4 butir f, dinyatakan bahwa pengaturan desa bertujuan meningkatkan pelayanan publik bagi warga masyarakat desa guna mempercepat perwujudan kesejahteraan umum. Sedangan dalam Pasal 7 ayat (3) butir c, disebutkan bahwa penataan Desa dimaksudkan untuk mempercepat proses pelayanan publik. Selanjutnya Pasal 67 ayat (2) butir e, menyatakan bahwa Desa berkewajiban memberikan dan meningkatkan pelayanan kepada masyarakat desa. Lebih lanjut, dalam Pasal 68 ayat (1) butir b disebutkan bahwa masyarakat desa berhak memperoleh pelayanan yang sama dan adil. Isu kesejahteraan mencakup dua komponen besar, yakni penyediaan layanan dasar (pangan, papan, pendidikan dan kesehatan) dan pengembangan ekonomi Desa yang berbasis pada potensi lokal.

Pada saat perundang-undangan memberikan ruang begitu luas menuju terwujudnya kemandirian desa, disaat berbarengan; beberapa peraturan yang mengatur dana desa mengalir seperti air bah memenuhi ruang-ruang kerja aparatur desa dirasa sebagai bentuk birokratisasi baru karena terlalu mengatur secara teknis dan prosedural hal-hal seperti dasar alokasi dana desa, pengelolaan dan pertanggungjawaban dana desa, prioritas penggunaan dana desa, pendirian Badan Usaha Milik Desa (BUMDes), dan sebagainya. Makna pemberdayaan desa yang menjadi intensi normatif dari UU Desa menjadi potensial terlupakan.

Menurut Yuyun Yulianah, di satu sisi sebagai satuan pemerintahan terkecil, desa memerlukan aparatur penunjang pemerintahan yang handal, yang mampu menggali potensi-potensi keuangan desa serta mampu memberikan pengayoman yang optimal kepada masyarakat. Akan tetapi di sisi lain, sumber daya manusia aparatur desa itu sendiri umumnya masih lemah dan terbatas. Sementara berbagai bantuan langsung diberikan oleh pemerintah kepada desa dalam berbagai bentuk dan variasinya, baik bantuan berupa dana tunai langsung, sarana atau alat maupun bentuk lain (bibit, benih, dan sebagainya). Bantuan-bantuan tersebut diberikan secara langsung melalui desa untuk disalurkan langsung kepada masyarakat agar masyarakat membudidayakannya. Akan tetapi dalam kenyataannya bantuan-bantuan tersebut ada yang tersalurkan kepada 
masyarakat ada pula yang tidak sampai, melainkan dimanfaatkan oleh kelompokkelompok tertentu. ${ }^{1}$

Selain itu, keterlambatan penyampaian laporan penggunaan Alokasi Dana Desa juga kerap kali terjadi karena tidak jelasnya aturan hukum yang mengatur mengenai hal tersebut, sumber daya manusia tidak mumpuni, perubahan anggaran, serta kurangnya koordinasi antar unit kerja yang satu dengan unit kerja yang lain. Penguatan pengetahuan aparat dan warga desa dalam pengambilan keputusan penggunaan dana desa sesuai kebutuhan dan kondisi yang dihadapi desa merupakan hal penting demi mengakan amanah undang-undang desa bersama dengan monitoring serta evaluasi penggunaan dana desa yang partisipatif melibatkan warga desa.

Berdasarkan uraian di atas, maka permasalahan penelitian ini adalah Bagaimana pelaksanaan pengelolaan dana desa dan penegakkan hukumnya berdasarkan undangundang Desa Nomor 6 Tahun 2014 di Kabupaten Lampung Timur, dan apa saja hambatan - hambatan dalam pengelolaan dana desa di Kabupeten Lampung Timur?

Ada beberapa jurnal ataupun penelitian yang relevan dengan penelitian yang akan dilakukan peneliti, diantaranya:

1. Penelitian Kemenristek Dikti, Putri Kartika Anggraini dan Herlin Wijayati Universitas Brawijaya, Malang tahun 2015 dengan judul "Implementasi Pengelolaan Alokasi Dana Desa Berdasarkan Peraturan Pemerintah Nomor 43 Tahun 2014 Tentang Peraturan Pelaksanaan Undang-Undang Nomor 6 Tahun 2014 (Studi Di Pemerintah Daerah Kabupaten Jombang)”, tentang pengelolaan alokasi dana desa berdasarkan Peraturan Pemerintah Nomor 43 Tahun 2014 tentang Peraturan Pelaksanaan Undang-Undang Nomor 6 Tahun 2014. keterlambatan penyampaian laporan penggunaan Alokasi Dana Desa Perbedaan dengan penelitian peneliti yaitu pada pembahasan penegakan pengelolaan dana desa.

2. Pembahasan selanjutnya adalah tentang Pertanggung jawaban Penggunaan Alokasi Dana Desa Pada Pemerintahan Desa di Kabupaten Donggala, membahas mekanisme pertanggungjawaban pemerintahan desa dalam penggunaan alokasi dana

\footnotetext{
${ }^{1}$ Yuyun Yulianah, "Potensi Penyelewengan Alokasi Dana Desa Di Kaji Menurut Peraturan Menteri Dalam Negeri Nomor 37 Tahun 2007 Tentang Pengelolaan Keuangan Desah," Jurnal Justicia Mimbar Vol. I, no. No. 02 (Desember 2015): 610-11.
} 
desa Perbedaan dengan penelitian peneliti yaitu pada pembahasan mekanisme pertanggungjawaban pemerintahan desa.

3. Tulisan selanjutnya adalah tentang Potensi Penyelewengan Alokasi Dana Desa Di Kaji Menurut Peraturan Menteri Dalam Negeri Nomor 37 Tahun 2007 Tentang Pengelolaan Keuangan Desa, membahas tentang kelemahan pengawasan terhadap alur proses mengalirnya dana, dan lemahnya Sumber Daya manusia dari Aparat Pemerintahan Desa itu sendiri. Perbedaan dengan penelitian peneliti yaitu pada sumber daya manusia aparat pemerintahan desa yang mengelola dana desa.

\section{Pembahasan}

\section{Konsep Desa}

Menurut Peraturan Pemerintah Nomor 43 Tahun 2014 tentang Peraturan Pelaksanaan Undang-Undang Nomor 6 Tahun 2014 Pasal 1, Desa adalah Desa dan Desa adat atau yang disebut dengan nama lain, selanjutnya disebut Desa, adalah kesatuan masyarakat hukum yang memiliki batas wilayah yang berwenang untuk mengatur dan mengurus urusan pemerintahan, kepentingan masyarakat setempat berdasarkan prakarsa masyarakat, hak asal-usul, dan/atau hak tradisional yang diakui dan dihormati dalam sistem pemerintahan Negara Kesatuan Republik Indonesia. ${ }^{2}$

Tujuan pembentukan desa adalah untuk meningkatkan kemampuan penyelenggaraan Pemerintahan secara berdaya guna dan berhasil guna dan peningkatan pelayanan terhadap masyarakat sesuai dengan tingkat perkembangan dan kemajuan pembangunan. Desa memiliki wewenang sesuai yang tertuang dalam Peraturan Pemerintah Nomor 6 Tahun 2014 tentang Desa yakni:

a. Menyelenggarakan urusan pemerintahan yang sudah ada berdasarkan hak asal-usul desa.

b. Menyelenggarakan urusan pemerintahan yang menjadi kewenangan kabupaten/kota yang diserahkan pengaturannya kepada desa, yakni urusan pemerintahan urusan pemerintahan yang secara langsung dapat meningkatkan pelayanan masyarakat.

\footnotetext{
2 anonymous, "Peraturan Pemerintah Nomor 43 Tahun 2014 tentang Peraturan Pelaksanaan UndangUndang Nomor 6," 2014.
} 
c. Tugas pembantuan dari pemerintah, Pemerintah Provinsi, dan Pemerintah Kabupaten/Kota.

d. Urusan pemerintahan lainnya yang oleh peraturan perundang-undangan diserahkan kepada desa.

Undang-Undang tentang Desa yang baru saja ditetapkan ini adalah undangundang pertama pasca-pencabutan Undang-Undang Nomor 5 Tahun 1979 tentang Pemerintahan Desa yang diamanatkan oleh reformasi. Sebelumnya, melalui pemberlakukan Undang-Undang Nomor 22 Tahun 1999 yang kemudian digantikan oleh Undang-Undang Nomor 32 Tahun 2004 tentang Pemerintahan Daerah, desa hanya diatur oleh peraturan-perundangan setingkat Peraturan Pemerintah.

Setidaknya ada 5 (lima) perubahan pokok yang dikandung dalam UU Desa yang baru. Kelima perubahan pokok itu tentu saja diaharpakan mampu memperbaiki kualitas kehidupan warga negara yang tinggal di desa-desa Indonesia. Perubahan-perubahan pokok dimaksud adalah, melalui UU Desa yang baru inilah untuk pertama kalinya desadesa yang ada di Negeri ini akan diatur melalui sistem pengaturan yang beragam. UU Desa yang baru memperkenakan dua jenis desa dan desa adat. Jika desa terbentuk berdasarkan ukuran-ukuran demografis dan adminsitratif, desa adat terbentuk karena desa adat itu memang memiliki sejarah dan hak asal usulnya.

Kelompok perubahan pokok kedua, berbeda dengan sistem pengaturan desa pada masa lalu yang diturunkan berdasarkan azas desentralisasi, sehingga desa adalah bagian dari Daerah Kabupaten, kewenangan desa saat ini diturunkan berdasarkan azas rekognisi dan subsidiaritas. Dengan begitu, desa sekarang juga memiliki kewenangan yang bersumber dari hak asal-usul dan adat-istiadat, disamping kewenangankewenangan lain yang dirutunkan dari azas-azas subsidiaritas dan perbantuan.

Perubahan-perubahan mendasar itu membutuhkan sistem pelaksanaan dan pengawasan kegiatan pembangunan dan pemerintahan di tngkat desa. Oleh sebab itu UU Desa ini juga membawa dan mendorong terjadinya proses demokratisasi di tingkat desa melalui partisipasi seluruh pihak yang ada di desa secara optimal. Serangkaian kegiatan pemberdayaan dan pendampingan juga harus dilakukan. Baik untuk 
kelembagaan desa maupun lembaga-lembaga kemasyaraatan. Termasuk dengan menyediakan informasi yang akurat dan transparan.

\section{Alokasi Dana Desa dan Pengelolaannya}

Dana desa adalah dana yang bersumber dari APBN yang diperuntukkan bagi yang ditransfer melalui APBD kabupaten dan kota yang digunakan untuk membiayai penyelenggaraan pemerintahan, pelaksanaan pembangunan, pembinaan kemasyarakatan. ${ }^{3}$

Undang-Undang Nomor 23 Tahun 2014 Tentang Pemerintahan Daerah mengatur secara khusus mengenai pendapatan daerah, yang di atur dalam Pasal 1 ayat 35 menyatakan bahwa "Pendapatan Daerah adalah semua hak Daerah yang diakui sebagai penambah nilai kekayaan bersih dalam periode tahun anggaran yang bersangkutan", dan pada Pasal 380 dalam penjelasan ayat 2, yaitu :

"Khusus untuk pengawasan yang terkait keuangan Daerah meliputi kegiatan audit, reviu, evaluasi, pemantauan, dan bimbingan teknis dalam pengelolaan APBD kabupaten/kota yaitu sejak tahap perencanaan, pelaksanaan, pemantuan dan evaluasi atas pelaksanaan APBD (termasuk penyerapan APBD), sampai dengan pertanggungjawaban pelaksanaan APBD kabupaten/kota yang dilakukan inspektorat kabupaten/kota dapat bekerja sama dengan Inspektorat Jenderal Kementerian dan/atau lembaga pemerintah nonkementerian yang menyelenggarakan urusan pemerintahan bidang pengawasan". 4

Lebih lanjut, dana desa yang di atur dalam Pasal 285 ayat 2 dalam penjelasan angka 4 yaitu : "Yang dimaksud dengan dana Desa adalah dana yang bersumber dari APBN yang diperuntukan bagi Desa yang ditransfer melalui APBD kabupaten/kota dan digunakan untuk membiayai penyelenggaraan pemerintahan Desa yang mencakup pelayanan, pembangunan, dan pemberdayaan masyarakat". 5

Menurut Peraturan Menteri Dalam Negeri Nomor 37 Tahun 2007 tentang Pedoman Pengelolaan Keuangan Desa pada Pasal 18 bahwa Anggaran Dana Desa

\footnotetext{
3 anonymous, "Peraturan Menteri Keuangan Republik Indonesia Nomor 241tentang Pelaksanaan Pertanggung jawaban Transfer ke Daerah dan Dana Desa.," 2014.

4 anonymous, "Undang-Undang Nomor 23 Tentang Pemerintahan Daerah," 2014.

5 anonymous.
} 
berasal dari APBD Kabupaten/Kota yang bersumber dari bagian Dana Perimbangan Keuangan Pusat dan Daerah yang diterima oleh Kabupaten/Kota ntuk desa paling sedikit $10 \%$ (sepuluh persen). ${ }^{6}$

Menurut Undang-Undang Nomor 6 Tahun 2014 tentang Desa pada Pasal 72 ayat (1) mengenai sumber pendapatan desa, dalam huruf d disebutkan " anggaran dana desa yang merupakan bagian dari dana perimbangan yang diterima Kabupaten/Kota". Selanjutnya dalam ayat (4) Pasal yang sama disebutkan "Anggaran Dana Desa sebagaimana dimaksud pada ayat (1) huruf d paling sedikit 10\% (sepuluh perseratus) dari dana perimbangan yang diterima Kabupaten/Kota dalam Anggaran Pendapatan dan Belanja Daerah setelah dikurangi Dana Alokasi Khusus".

Dana Desa setiap kabupaten/kota dialokasikan berdasarkan perkalian antara jumlah di setiap kabupaten/kota dan rata-rata Dana Desa setiap provinsi. Rata-rata Dana Desa setiap provinsi dialokasikan berdasarkan jumlah desa dalam provinsi yang bersangkutan serta jumlah penduduk kabupaten/kota, luas wilayah kabupaten/kota, angka kemiskinan kabupaten/kota, dan tingkat kesulitan geografis kabupaten/kota dalam provinsi yang bersangkutan.

Besaran Dana Desa setiap Desa sebagaimana dimaksud pada ayat (1) Peraturan Pemerintah Nomor 60 Tahun 2014 tentang Dana Desa yang Bersumber dari Anggaran Pendapatan dan Belanja Neagara, dihitung berdasarkan jumlah penduduk desa, luas wilayah desa, angka kemiskinan Desa, dan tingkat kesulitan geografis. ${ }^{8}$ Jumlah penduduk Desa, luas wilayah Desa, dan angka kemiskinan Desa sebagaimana dimaksud pada ayat (2) dihitung dengan bobot:

a. 30\% (tiga puluh perseratus) untuk jumlah penduduk Desa;

b. $20 \%$ (dua puluh perseratus) untuk luas wilayah Desa; dan

c. $50 \%$ (lima puluh perseratus) untuk angka kemiskinan. ${ }^{9}$

\footnotetext{
6 anonymous, "Peraturan Menteri Dalam Negeri Nomor 37 tentang Pedoman Pengelolaan Keuangan Desa," 2007.

${ }^{7}$ Lihat pasal 72 Ayat (1) Undang-Undang Nomor 6 Tahun 2014 tentang Desa.

8 Pasal 11 ayat (1) Peraturan Pemerintah Republik Indonesia Nomor 60 Tahun 2014 yang dimaksud dengan jumlah Desa adalalah jumlah Desa yang ditetapkan oleh menteri, dan pada Pasal 12 ayat (2) yang dimaksud dengan angka kemiskinan adalah presentase rumah tangga pemegang Kartu Pelindung Sosial.

9 Pasal 12 ayat (2) dan (3) Peraturan Pemerintah Republik Indonesia Nomor 60 Tahun 2014 Tentang Dana Desa Yang Bersumber Dari Anggaran Pendapatan Dan Belanja Negara.
} 
Tingkat kesulitan geografis setiap Desa sebagaimana dimaksud pada ayat (2) digunakan sebagai faktor pengalihasil penghitungan sebagaimana dimaksud pada ayat (3). Besaran Dana Desa setiap Desa sebagaimana dimaksud pada ayat (1) dihitung dengan cara:

a. Dana Desa untuk suatu Desa $=$ Pagu Dana Desa kabupaten $/$ kota $\mathrm{x}[(30 \% \mathrm{x}$ persentase jumlah penduduk desa yang bersangkutan terhadap total penduduk desa di kabupaten/kota yang bersangkutan $)+(20 \%$ x persentase luas wilayah desa yang bersangkutan terhadap total luas wilayah desa di kabupaten/kota yang bersangkutan) $+(50 \%$ x persentase rumah tangga pemegang Kartu Perlindungan Sosial terhadap total jumlah rumah tangga desa di kabupaten/kota yang bersangkutan)];dan

b. hasil penghitungan sebagaimana dimaksud pada huruf a disesuaikan dengan tingkatkesulitan geografis setiap desa.

c. Tingkat kesulitangeografis sebagaimana dimaksud pada ayat (4) ditentukan oleh faktor yang meliputi:

1) Ketersediaan pelayanan dasar;

2) Kondisi infrastruktur;

3) Transportasi; dan

4) Komunikasi desa ke kabupaten/kota. ${ }^{10}$

Peraturan Mentri Dalam Negeri Nomor 4 Tahun 2007 Pasal 1 menjelaskan bahwa yang dimaksud dengan pengelolaan adalah rangkaian kegiatan mulai dari perencanaan, pengadaan, penggunaan, penatausahaan, penilaian, pembinaan, pengawasan dan pengendalian. Pengelolaan atau disebut juga dengan manajemen dalam pengertian umum adalah suatu seni, ketrampilan, atau keahlian. ${ }^{11}$

Pemerintah desa wajib mengelola keuangan desa secara transparan, akuntabel, partisipatif serta dilakukan dengan tertib dan disiplin. Transparan artinya dikelola secara terbuka, akuntabel artinya dipertanggungjawabkan secara legal, dan partisipatif artinya melibatkan masyarakat dalam penyusunannya. Keuangan desa harus dibukukan dalam

${ }^{10}$ Lihat Pasal 12 Ayat (4) dan (5) Peraturan Pemerintah Republik Indonesia Nomor 60 Tahun 2014 Tentang Dana Desa Yang Bersumber Dari Anggaran Pendapatan Dan Belanja Negara.

${ }^{11}$ Lihat Pasal 1 Peraturan Mentri Dalam Negeri Nomor 4 Tahun 2007 
sistem pembukuan yang benar sesuai dengan kaidah sistem akuntansi keuangan pemerintahan. $^{12}$

Kepala Desa adalah pemegang kekuasaan pengelolaan keuangan desa, dalam melaksanakan kekuasaan pengelolaan keuangan desa kepala desa menguasakan sebagian kekeuasaannya kepada perangkat desa. Oleh sebab itu, berhasil tidaknya pengelolaan dana desa tergantung pada kepala desa. ${ }^{13}$

\section{Penegakan Undang-Undang Desa}

Pemerintah daerah kabupaten/kota, paling sedikit mengalokasikan 10\% dari dana perimbangan yang diterima kabupaten/kota dalam Anggaran Pendapatan dan Belanja Daerah kabupaten/kota untuk Alokasi Dana Desa setiap tahun anggaran. Alokasi Dana Desa (ADD) merupakan sumber utama Anggaran Pendapatan dan Belanja Desa dan kerap kali sering disebut sebagai sisa-sisa dari uang kabupaten. Meskipun kecil, Alokasi Dana Desa mempunyai banyak manfaat di desa. ${ }^{14}$

Anggaran sebesar 10\% ini diharapkan akan meningkatkan kesejahteraan dan pemerataan pembangunan di desa. Pengelolaan Alokasi Dana Desa adalah kewenangan Pemerintahan Desa. Pengelolaan Alokasi Dana Desa merupakan bagian yang tidak terpisahkan dari pengelolaan keuangan desa yang dituangkan dalam peraturan desa tentang Anggaran Pendapatan dan Belanja Desa. Oleh karena itu, pengelolaan keuangan desa tidak dibenarkan diambil oleh Pemerintah atau pemerintah Daerah. ${ }^{15}$

Penggunaan Anggaran Alokasi Dana Desa adalah sebesar 30\% (tiga puluh persen) untuk belanja aparatur dan operasional Pemerintah Desa, sebesar 70\% (tujuh puluh persen) untuk biaya pemberdayaan masyarakat. Bagi Belanja Pemberdayaan Masyarakat digunakan untuk Biaya perbaikan sarana publik dalam skala kecil, penyertaan modal usaha masyarakat melalui BUMDesa, biaya untuk pengadaan ketahanan pangan, perbaikan lingkungan dan pemukiman, teknologi tepat guna,

\footnotetext{
${ }^{12}$ Nurcholis Hanif, Pertumbuhan Dan Penyelenggaraan Pemerintah Desa (Jakarta: Erlangga, 2011).

${ }^{13}$ Virgie Delawillia Kharisma, “Implementasi Kebijakan Pemanfaatan Alokasi Dana Desa," t.t., 10.

${ }^{14}$ Sutoro, dkk, Desa Membangun Indonesia (Yogyakarta: FPPD, 2014).

${ }^{15}$ Wahjudin Sumpeno, Perencanaan Desa Terpadu, Kedua (Banda Aceh: Read, 2011).
} 
perbaikan kesehatan dan pendidikan, pengembangan sosial budaya, dan sebagainya yang dianggap penting. ${ }^{16}$

Pengawasan terhadap Alokasi Dana Desa beserta kegiatan pelaksanaannya dilakukan secara fungsional oleh pejabat yang berwenang dan oleh masyarakat sesuai dengan Peraturan Perundang-Undangan yang berlaku. Jika terjadi penyimpangan atau penyalahgunaan Alokasi Dana Desa, maka penyelesaiannya secara berjenjang, sesuai dengan ketentuan perundangan yang berlaku. Pengawasan pelaksanaan alokasi dana desa tidak terlepas dari struktur tugas dan kewenangan serta pertangungjawaban sebagaimana disusun dalam struktur organisasi pelaksana. ${ }^{17}$

Organisasi atau satuan kerja perangkat daerah (SKPD) yang memonitoring jalannya alokasi dana desa pada setiap mulai penyusunan anggaran, penatausahaan (pencairan dana ) sampai dengan pertanggung jawabannya yaitu Badan Pemberdayaan Masyarakat dan Pemerintahan Desa dan semua kecamatan yang ada dalam satu Kabupaten. Pertanggungjawaban alokasi dana desa (ADD) terintegrasi dengan pertanggung jawaban APBDesa, sehingga bentuk pertanggung jawabannya adalah pertanggung jawaban APBDesa. ${ }^{18}$

Penyampaian laporan dilaksanakan melalui jalur struktural, yaitu dari tim pelaksana tingkat desa dan diketahui kepala desa ke tim pendamping tingkat kecamatan secara bertahap. Tim pendamping tingkat kecamatan membuat laporan/ rekapan dari seluruh laporan tingkat desa di wilayah dan secara bertahap melaporkannya kepada bupati cq. Tim fasilitas tingkat kabupaten/ kota. Pembiayaan dalam rangka pelaksanaan tugas pendampingan tim pendamping dibebankan kepada APBD kabupaten diluar dana Alokasi Dana Desa (ADD). ${ }^{19}$

\section{Faktor-Faktor Yang Mempengaruhi Penegakan Undang-Undang Desa}

Berdasarkan identifkasi tersebut diatas maka terdapat faktor-faktor yang mempengaruhi dari penegakan undang-undang desa nomor 6 tahun 2014 terhadap

\footnotetext{
${ }^{16}$ Agisma Dyah Fastari, Inti Wasiati, dan Jln Kalimantan, “Alokasi Dana Desa dalam Formulasi Kebijakan APBD Kabupaten Jember Tahun 2012" 1 (2012): 9.

${ }^{17}$ Fastari, Wasiati, dan Kalimantan.

18 Paulus Israwan Setyoko, “Akuntabilitas Administrasi Keuangan Program Alokasi Dana Desa (ADD)," t.t., 11.

${ }^{19}$ Hasman Husin Sulumin, Pertanggung jawaban Penggunaan, t.t.
} 
pengelolaan pelaksanaan dana desa di Kabupaten Lampung Timur adalah sebagai berikut:

Desa Pematang Tahalo, terdapat permasalahan sebagai berikut:

a. Aparat Desa yang masih belum memahami sesungguhnya tentang Pengelolaan Pelaksanaan Dana Desa di Kabupaten Lampung Timur.

b. Aparat Desa yang sudah memahami tentang Pengelolaan Pelaksanaan Dana Desa di Kabupaten Lampung Timur.

c. Aparat Desa yang dipandang dapat memahami dan mengerti tentang Pengelolaan Pelaksanaan Dana Desa di Kabupaten Lampung Timur.

Dari hasil identifikasi di atas maka prosentase permasalahannya adalah sebagai berikut:

a. Untuk prosentase permasalahan pada point pertama $16,67 \%$ yang tidak memahami tentang Pengelolaan Pelaksanaan Dana Desa yang ada di Kabupaten Lampung Timur.

b. Untuk prosentase permasalahan pada point kedua $66,67 \%$ yang sudah memahami tentang Pengelolaan Pelaksanaan Dana Desa yang ada di Kabupaten Lampung Timur.

c. Untuk prosentase permasalahan pada point ketiga $16,67 \%$ yang dipandang mampu mengamalkan Pengelolaan Pelaksanaan Dana Desa yang ada di Kabupaten Lampung Timur.

Adapun dari Desa Taman Bogo terdapat permasalahan sebagai berikut:

a. Aparat Desa yang masih belum memahami sesungguhnya tentang Pengelolaan Pelaksanaan Dana Desa di Kabupaten Lampung Timur.

b. Aparat Desa yang sudah memahami tentang Pengelolaan Pelaksanaan Dana Desa di Kabupaten Lampung Timur.

c. Aparat Desa yang dipandang dapat memahami dan mengerti tentang Pengelolaan Pelaksanaan Dana Desa di Kabupaten Lampung Timur.

Dan dari hasil identifikasi di atas, prosentase permasalahannya adalah sebagai berikut: 
a. Untuk prosentase permasalahan pada point pertama 50,00\% yang tidak memahami tentang Pengelolaan Pelaksanaan Dana Desa di Kabupaten Lampung Timur.

b. Untuk prosentase permasalahan pada point kedua 33,33\% yang sudah memahami tentang Pengelolaan Pelaksanaan Dana Desa di Kabupaten Lampung Timur.

c. Untuk prosentase permasalahan pada point ketiga $16,67 \%$ yang sudah memahami tentang Pengelolaan Pelaksanaan Dana Desa di Kabupaten Lampung Timur

Berdasarkan data yang diperoleh dari hasil penelitian terhadap 12 orang informan pada masing-masing desa, maka terdapat permasalahan tentang Penegakan Undang-undang Desa Nomor 6 Tahun 2014 Terhadap Pengelolaan Pelaksanaan Dana Desa di Kabupaten Lampung Timur.

1. Faktor yang berkaitan dengan kurangnya pemahaman terhadap pengelolaan pelaksanaan dana desa dalam prosentase mencapai 33,33\% dari total 12 informan dari 2 lokasi, yaitu desa Pematang Tahalo dan Taman Bogo di Kabupaten Lampung Timur.

2. Faktor yang berkaitan dengan sudah memahami tentang pengelolaan pelaksanaan dana desa dalam prosentase mencapai 50,00\% dari total 12 informan dari 2 lokasi, yaitu desa Pematang Tahalo dan Taman Bogo di Kabupaten Lampung Timur.

3. Faktor yang berkaitan dengan sudah memahami dan sudah mengerti tentang pengelolaan pelaksanaan dana desa dalam prosentase mencapai 16,67\% dari total 12 informan dari 2 lokasi, yaitu desa Pematang Tahalo dan Taman Bogo di Kabupaten Lampung Timur.

\section{Kesimpulan}

Dalam pelaksanaan pengelolaan dana desa di Lampung Timur masih terlihat kurangnya pengelolaan yang baik dalam hal pelaksanaan Dana Desa mulai dari proses perencanaan, pelaksanaan sampai dengan serah terima dikarenakan pemahaman yang berbeda-beda di tingkat desa sehingga menimbulkan banyak persepsi terkait Dana Desa.

Kemudian ada beberapa hambatan-hambatan dalam pelaksanaan dana Desa, diantaranya :

a. Masih rendahnya tingkat pendidikan aparat desa mulai dari Kepala Desa, Sekretaris Desa, Bendahara Desa, Kaur Pembangunan, Kaur Pemerintahan dan Kepala Dusun 
sehingga mengakibatkan lambatnya Transfer Knowledge terhadap program Dana Desa yang akan terus berkelanjutan yang merupakan amanat dari Undang-undang.

b. Kurangnya peningkatan kapasitas melalui pelatihan bagi para pengelola Dana Desa yang menyebabkan terlambatnya pembuatan laporan atau pertanggungjawaban penyerapan dana.

\section{Daftar Pustaka}

anonymous. "Peraturan Menteri Dalam Negeri Nomor 37 tentang Pedoman Pengelolaan Keuangan Desa,” 2007.

—. "Peraturan Menteri Keuangan Republik Indonesia Nomor 241tentang Pelaksanaan Pertanggung jawaban Transfer ke Daerah dan Dana Desa.,” 2014.

—_. "Peraturan Pemerintah Nomor 43 Tahun 2014 tentang Peraturan Pelaksanaan Undang-Undang Nomor 6," 2014.

—_. "Undang-Undang Nomor 23 Tentang Pemerintahan Daerah,” 2014.

Fastari, Agisma Dyah, Inti Wasiati, dan Jln Kalimantan. “Alokasi Dana Desa dalam Formulasi Kebijakan APBD Kabupaten Jember Tahun 2012” 1 (2012)

Hasman Husin Sulumin. Pertanggung jawaban Penggunaan.

Kharisma, Virgie Delawillia. "IMPLEMENTASI KEBIJAKAN PEMANFAATAN ALOKASI DANA DESA,” t.t., 10.

Nurcholis Hanif. Pertumbuhan Dan Penyelenggaraan Pemerintah Desa. Jakarta: Erlangga, 2011.

Setyoko, Paulus Israwan. "Akuntabilitas Administrasi Keuangan Program Alokasi Dana Desa (ADD)," t.t., 11.

Sutoro, dkk. Desa Membangun Indonesia. Yogyakarta: FPPD, 2014.

Wahjudin Sumpeno. Perencanaan Desa Terpadu. Kedua. Banda Aceh: Read, 2011. 
Yuyun Yulianah. "Potensi Penyelewengan Alokasi Dana Desa Di Kaji Menurut Peraturan Menteri Dalam Negeri Nomor 37 Tahun 2007 Tentang Pengelolaan Keuangan Desah.” Jurnal Justicia Mimbar Vol. I, no. No. 02 (Desember 2015).

Etzioni dkk, Organisasi-Organisasi Modern, Jakarta: UIPress, 1985

Jonathan Sarwono, Metode Penelitian Kuantitatif dan Kualitatif, Yogyakarta: Graha Ilmu, 2006

Lubis Hari S.B. dan Martani Husaini, Teori Organisasi (Suatu Pendekatan Makro), Jakarta: Pusat Antar Ilmu-ilmu Sosial,1987

Mahmudi, Manajemen Kinerja Sektor Publik, Jakarta: UPP STIM YKPN, 2005

Morrison, Metode Penelitian Survei, Jakarta: Kencana, 2012

M. Subana, Sudrajat, Dasar-Dasar Penelitian Ilmiah, Bandung: Pustaka Setia, 2001

Richard M. Steers , Efektivitas Organisasi ,Jakarta: Erlangga,1985

S.P. Siagian, Admiinistrasi Pembangunan Konsep, Dimensi, dan Strateginya, Jakarta: Gita Karya,1978

Suharsimi Arikunto, Prosedur Penelitian Suatu Pendekatan Praktek, Jakarta: Rineka Cipta, 1998 